\title{
The Double-Tongued Author: Re-reading Sophocles, Thomas Hardy, and Eduard Vilde
}

\author{
ARNE MERILAI
}

\begin{abstract}
The article discusses the authors' ambivalent attitude towards their protagonists, drawing on Sophocles' Oedipus the King, Thomas Hardy's Tess of the d'Urbervilles, and Eduard Vilde's Mäeküla piimamees (Milkman of the Manor). Firstly, the hypothesis based on Aristotle's Poetics and the idea of Pericles having been a possible prototype of Oedipus is proposed, according to which Sophocles could have been critical of the tyrant of Thebes as a noble representative of a polis at war with Athens, justifying his pains in addition to showing compassion. Such an interpretation is in contrast with the humanist and protest-driven glorification initiated by Friedrich Nietzsche. Another example of the author's "hypocrisy" is Thomas Hardy's novel that is generally, and with reason, read as critical of Victorian society. However, the work's reception has failed to address the motif of mystical revenge on the inheritor of the bloodline of foreign conquerors that occurs in the shadow of a woman's tragedy and is executed with consistency, yet is not seen as the text's rival dominant. Still, without considering the opposing line of interpretation that constitutes a parallel in its tragic irony, the understanding of the novel will remain superficial. The third example of the author's split viewpoint can be found in the first Estonian novel to excel in artistic maturity that also stands out as the first psychological and erotic novel. Vilde's social-critical programme in the name of the oppressed country people and women's emancipation clashes in an intriguing way with his erotomanic objectifying gaze on the woman which rather represents a patriarchal attitude bent on subordinating the other sex. Vilde's ambivalence towards his wayward heroine makes her a most interesting character whose mystery cannot be solved unequivocally.
\end{abstract}

Keywords: Sophocles; Oedipus the King; Thomas Hardy; Tess of the d'Urbervilles; Eduard Vilde; Mäeküla piimamees; ambivalence; deconstruction; comparativism; reception; poetics

1 This work was supported by institutional research funding IUT (No 20-1; 2014-2019) of the Estonian Ministry of Education and Research.

DOI: https://doi.org/10.12697/IL.2018.23.2.9 
MERILAI

Artistic language is, in many respects, ambiguous. This includes associative connectivity, metaphorical openness, ironic duplicity, and the difference between focuses of content and expression. A trope is described as saying one thing, but thinking another; a text manifests both its own language and, with the help of language, meaning in a work. The subject of this article is again a duplicity: the concealed or unconcealed double-tongueness of an author with respect to his protagonist.

I will observe three possible cases of authorial ambivalence in Oedipus the King, Tess of the d'Urbervilles, and Mäeküla piimamees ('Milkman of the Manor'), written by the first Estonian novelist Eduard Vilde (see also Merilai 2016). In the context of this thesis, these works seem to be typologically similar. To varying degrees, all three are accompanied by fixed translations of overwhelming humanistic glorification, and their core concepts have remained unchallenged. Their messages seem set in stone: human heroic attempts at freedom and emancipation; protest against restrictive situations - divine, patriarchal, political, classical; the social abjection of another person or a woman, and the condemnation of said abjection; tragic suffering, disaster, death, and salvation; the pressure of losing and the struggle to be free; the contradiction of conventions on moral purity; attempts to improve the world through human suffering, fear, and compassion; the application of catharsis. Of course, this is all correct, and it is not the target of my subsequent deconstruction; rather I focus on the way thought ceases beneath a concrete layer of partial truths.

The two-faced narrative mode can also be called narrative counterpoint, a term borrowed from the musical genre. This is illustrated in the diagram below in which the implicit subtext runs parallel to the explicit main plot, creating a dialogic field of tension between the two levels. A subjective alternative may have been requested by the author, as seems to be the case for the first two works by Sophocles and Hardy, or unrequested accompaniment, as is better characterized by Vilde's novel.

\section{NARRATIVE COUNTERPOINT}

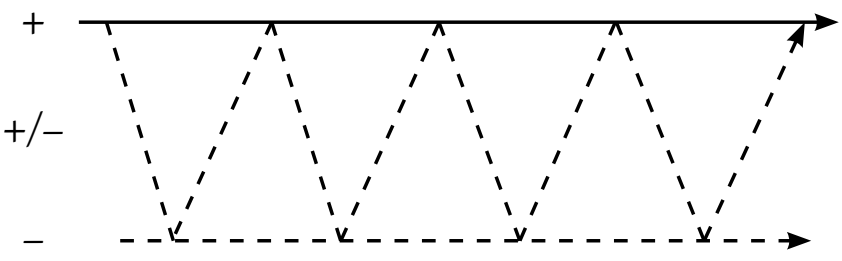


The Double-Tongued Author

\section{Sophocles' Oedipus the King}

The humanist interpretation of Oedipus is based primarily on the heroic concept. The Apollonian idealist, Hegel, discusses this in the first part of Lectures on Aesthetics when he describes how, during the heroic age of Greece, the subject was fully responsible for everything that affected him; he did not share fault nor push it away, even if the incident happened accidentally. Although Oedipus, unknowingly, killed his father in self-defense and married his mother, as soon as he became aware of it, he did not hesitate to take all the responsibility. The contemplative mentality of the new age would have considered him to be innocent, but this does not coincide with the self-evident morality of heroic purity, which believes everything touched by man to be connected. Punishment was not to be avoided, but completely and inarguably embraced. Even more so, since sin was considered a hereditary curse, requiring the best of oneself for redemption (Hegel 1976: 188).

Hegel's romantic successor, the Dionysian Nietzsche, whose interpretations were full of dark urges that Freud also followed, elevates the Oedipus character to a rather pre-superhuman position. Compared to mainstream writers, Nietzsche, a guaranteed alternative, perhaps also in self-projection, praises the smart and heroic ruler, who, from beneath the mask of the Apollonian gesture of performing arts, presents a brave and radical challenge to gods, myth, and nature, founding a new moral reality for his own demise (Nietzsche 2017: IX).

Hegel's and Nietzsche's superlative pathos formed the general direction for art that later gained traction and continued, for example, in Julia Kristeva's abjection theory, which describes the tragic fate of Oedipus in divine contrast as a pre-Christian and feminist redeemer (Kristeva 1982: 83-85). In Kristeva's interpretation, "such is the blinding light" cast by Freud on abjection, following Oedipus, as he invites us to recognize ourselves in it without gouging out our eyes (1982: 130). Gilles Deleuze and Félix Guattari (2004), who praise Freud for his liberation of the alienated psyche in libido theory but criticize him for a fixation of the libido in the Oedipal father-mother-me triangle that rebuilds the discourse of capitalism, suggest freeing Oedipus' depiction of worth from the mismanagement of culture - to return it to its natural and free surface. Either way, heroic respect and praise for Oedipus remains a unifying line of the humanist legacy, which has drenched the late and post-modern European cultural consciousness.

However, moving closer in time to Sophocles, the original deconstructive rift appears beneath a shiny lacquer - a striking contradiction to the glorious attitude of Oedipus. It turns out that contemporary Attic philosophy and logic, as opposed to the newly-fitted canon, did not consider Oedipus by any means 
MERILAI

to be the most sacred character (Aristoteles 2013: XIII). On the contrary, it reduces Oedipus to a distinct second tier, or "in-between" character, who may invoke fear and awaken compassion and subsequent purification, without shocking the audience. Although Aristotle is unambiguous, it is common practice today to overlook the current hierarchy of tragic heroes clearly differentiated by him. The philosopher states that, although characters like Oedipus or Thyestes are not the most virtuous, just, or respectable in their origins, they are not detrimentally immoral, and are struck by misfortune through misconceptions. For the Athenian democratic public, they are, therefore, easier to identify with, having only average levels of grandeur - people "like ourselves." The reason Aristotle's rankings for heroes is ignored today has a lot to do with Nietzsche, whose system disagreed with such a golden ratio. Classically in aesthetics, tragedy has been interpreted as divine doom, but if art in the modern age was able to "shockingly" execute the most noble characters to achieve maximum tension of contrast and, retrospectively, moral superiority, then the Hellenists did not consider the latter twist to be beautiful and thus left their sanctity untouched.

Let us now remove ourselves a bit from the traditional cultural narrative and restore assumptions of context to establish a hypothesis of a possible prototype. Who was King Oedipus in the eyes of the Athenians? Ancient ruler of Thebes, a central city-state in northern Boeotia. According to Aristotle, a dignified, but not the most dignified stateman. Why? Perhaps one may bring forth the obvious circumstances: that Oedipus was a chosen king, or tyrant, whose form of governance was, under the guise of the best interests for the citizens of democratic Athens, abandoned and not to be restored anymore, while fending off aristocratic opposition. Although the closest neighbors to the Thebans were kindred and not barbarians, incidents with them as direct enemies resulted in several bloody battles during Sophocles' lifetime. While the Boeotians were forced to cooperate with invaders from Persia, they were also considered great traitors. Therefore, there was no real historical reason for them or their rulers to sympathize; rather one could assume that the misfortunes befalling the enemies were quite enjoyable to the public and not counter-intuitive. Nevertheless, the Greeks were characterized by an evolving generosity and other cultural virtues, whose capacity for generalizing rose higher than mere enmity. As promised, the Spartans, occupying Athens in the year of Sophocles' death, organized an honorable funeral for him, though he had been an Athenian strategos and a member of Pericles' government, which had previously attacked Spartans.

One should probably search for the real prototype of Oedipus' stage form in the personality of Pericles himself, which the local demos required leading up to the emotional awakening and catharsis. This partially up-to-date interpretation 
is represented in the thorough and detailed monograph Sophocles and Pericles (1954) written by Oxford's classical philologist Victor Ehrenberg. Ehrenberg proves factologically, textologically, and logically - still in many respects hypothetically - how one could see Sophocles' contemporary and competitor, the Athenian political leader Pericles, embodied in Oedipus' character. Moreover, one may even recognize the "tyranny" of Pericles in Creon's character from the tragedy of Antigone, a character in seeming opposition to Oedipus, who had a similar conviction and plan of action, or, in other words, Pericles' rational individualism. Strikingly, although apparently unjustifiably, Creon is also called a strategos - or general - which the elected king could not have been.

The Athenians tended to support the militant and smart, though the reluctantly self-conscious reformer Pericles, who was a capable leader and skillful commander. In an era of intermittent wars, there was undoubtedly a necessity to follow him. But despite all the democracy, the self-centered strategos became more autocratic throughout the course of governing. In everyday life, he was self-absorbed and overly secular. His moralistic austerity and rationality were not tolerated by the most affluent nor by the more god-fearing citizens - both sides characterized by Sophocles. Considering the religious feelings of the playwright, who maintained the supremacy of divine timeless manners in the face of human and temporal laws, the master of tragedy may have even possibly voted against Socrates, who was allegedly accused of ruining youths in sacrilegious ways. Fortunately, such a fact will never become a part of the world's cultural history, because the ninety-year-old dramatist (496406 BC) wisely left earlier when the creator of Western philosophy (470-399 BC) was given a poisoned chalice. But the main conflict of Antigone and the statesman Creon developed on the same plane: Oedipus' brave daughter must choose between the community's customs, i.e., whether to commit blasphemy or treason, when the customary burial for her brother, killed in battle, would also end up paying respect to a national enemy. These kinds of moral conflicts between the narrow domestic-political and broad traditional perspective occurred often in Attica.

The people also reproached Pericles for living with the suspicious immigrant Aspasia. For the beautiful and witty Aspasia, Pericles abandoned his first wife, a close relative, who already had a child from a previous marriage, and gave her away to a third husband. Though Pericles adored Aspasia, dissatisfied citizens attacked her with accusations. The same kind of accusations were also levelled at the atheistic philosopher of the mind, Anaxagoras, who was Pericles' close friend. Many disliked the leader forcing his will onto others. His brash and fanciful innovations, which sometimes preferred temporal political factions to 
MERILAI

traditional laws, were a frequent problem, especially of course when collecting taxes. Sophocles, while both a colleague and a competitor, set up divine and thus eternal unwritten laws. He was characteristically more hedonistic, faithful, and conservative. Naturally, political and personal disagreements were mitigated by patriotic love and cooperation was abundant in all governments, but ideological conflicts were strong and different lines of power ran through the whole polis.

Pericles had apparently mocked the dramatist for aspiring to be a strategos, since the latter allegedly had dirty hands and hazy eyes and being a leader demanded moral purity and clarity of sight. Sophocles had namely been desirous of boys and parties, often deviating from his goals. But Sophocles also played an important role as a popular representative in Pericles' government, managing the redistribution of money and authoritatively balancing different political directions. He placed himself between oligarchs and democrats, albeit clearly remaining on the god-fearing side.

Pericles (495-429 BC) got to see Antigone (442 BC) in person, but by the time Oedipus (about 429 BC) was staged, he was probably already with Hades, having fallen seriously ill with the plague the same year and dying like his sons before him. Many simple-minded citizens believed a curse killed him for his sins. As is known, the plague was the fear-inducing setting that started the events of the tragedy of Oedipus. Maybe the recent ill fortune of an admired leader changed something in the public consciousness, but Oedipus the King did not win the drama competition; it was placed second instead - as historical cultural irony. A later example of the Theban trilogy, Oedipus at Colonus (staged posthumously in $401 \mathrm{BC}$ ), reaches a new level in the tragic genre - the death of the hero marks the beginning of a better life when the gods lift him to heaven. Can we presume this is the author's wish for reconciliation and redemption? Thus, blinded Oedipus did not stay in Hades, where, in his great shame, he could avoid facing his loved ones, looking forward instead toward a higher and brighter afterlife.

When comparing the creation of tragedy to that of comparative history, one could argue that the author had no reason to treat his main character with the unyielding positivity that has become canonical in modern reception. Oedipus, as the ruler of hostile Thebes, or secondly as the symbol for Pericles who created a lot of tension and controversy, had to suffer in accordance with how good a man he believed himself to be. The concrete parallel with Pericles undoubtedly facilitated a way for viewers to identify with Oedipus, to experience fear, compassion and purification, which could not simply be achieved with the addition of an archenemy character. According to Ehrenberg, Sophocles was more likely to confront Oedipus' and Creon's human hybris and praise divine 
punishment, forming the crossroads for later humanistic interpretation. The Athenian public opposed a self-righteous person disrupting the divine world order, which creates the tragic irony of destiny, torturous for the audience, to be eventually cancelled by turning a blind man into a seer. Blindness is a small matter next to being thrown into the chaos of cosmos; rather it is a joyous message, if through this harmony is returned to the world. Sophocles therefore advocated human obedience to eternal laws, not selfish opposition to them; although today, he has paradoxically become a preacher for the opposite side. But according to Ehrenberg, even the historical right belonged more to the reserved and forward-thinking Sophocles than the eager reformer Pericles even though he was also in favor of the triumphant idea of democracy - because it was actually his hectic and idealistic reorganizations that led to the gradual decline of Athens during the senseless Peloponnesian wars.

Such a reconstruction and subsequent deconstruction leads to a clearly contradictory result when compared with Nietzsche's amplified glorification of Oedipus. Accordingly, it appears that in addition to superficial accompaniment, the author also had a deeper, more critical point of view, which makes his attitude toward us initially, perhaps unexpectedly, ambivalent. One would not consider it, however, to be cruel hypocrisy insofar as sympathy and empathy have been fully utilized. Should we not think, however, that what is natural in King Lear or The Hunchback of Notre Dame was not strange already in antiquity? The author creates characters to methodically destroy them - to release intense thoughts and emotions that accompany this act and to encourage protest. Perhaps Sophocles did not challenge gods in the name of human emancipation, as was believed in later interpretations, but rather in the name of the false, selfish, and unrestrained person himself. Undoubtedly, Oedipus was at the same time Sophocles' favorite character, whose full compassion was added retrospectively, but since art functions according to principles of contrast, the tyrant is still a victim of the author's creativity. The author only begins thinking of his own absolution after recognizing his role as a creator at the end of his own life, equating himself more closely with his own hero. One prerequisite for this was proclaiming old Oedipus, who had been abandoned by the corrupt Thebans, a welcome citizen of Athens, accepted by the king Theseus and the people. This motif shows how important the distinction of "us" versus "them" was to the Athenians. Colonus, a village located near Athens, was the birthplace of Sophocles.

But the breakdown of understanding transpired not only between antiquity and the new age, but also between Sophocles and the preceding ages before him. For instance, by comparing descriptions of Oedipus in Homer's epic to those within the tragedies, we find that the masters of tragedy added many new and 
MERILAI

previously unknown twists and turns to the original myth. The Iliad's $23^{\text {rd }}$ song, "In Ceremonies for Patroclus" (Homer 1903: 229; 23.679-680), mentions the Theban athletic games in honor of the late Oedipus, which already contradicts Sophocles, because sports games were only held for the honorably deceased, not despised exiles. In the Odyssey, however, we find a more detailed description in the 11th song, "Odysseus in Hades" (Homer 1919: 11. 271-280), whose prose translation reads as follows:

And I saw the mother of Oedipodes, fair Epicaste, who wrought a monstrous deed in ignorance of mind, in that she wedded her own son, and he, when he had slain his own father, wedded her, and straightaway the gods made these things known among men. Howbeit he abode as lord of the Cadmeans in lovely Thebe, suffering woes through the baneful counsels of the gods, but she went down to the house of Hades, the strong warder. She made fast a noose on high from a lofty beam, overpowered by her sorrow, but for him she left behind woes full many, even all that the Avengers of a mother bring to pass.

We see that Homer does not have the succeeding offspring of Cadmus, founder of Thebes, immersed in such diverse troubles as occur in Sophocles' work. Oedipus' beautiful mother, Epicaste (also the name of Homer's own mother), flirts with Odysseus in Hades. However, as befitting a hero, a grand and honorable funeral is arranged for the anguished Oedipus, who was left to rule the city as a childless widow after his mother-wife committed suicide. Thus, in the epics, Oedipus was clearly not considered to be a despised and cursed selfexiled outcast. Also, Homer made no mention of Oedipus' eyes being gouged out, which the legendarily blind bard would have definitely noted. With regards to the wedding with his mother - the gods immediately made this known to the people, thus ensuring there would be no chance for a long-lasting marriage and four cursed children to carry on the family's misfortune. Though we do not know of the additions to the myth's plot by Aeschylus and the earlier tragedians, one may still presume that the brilliant Sophocles added quite a few of his own innovations, deepening the misery and despair of the ridiculed abject to reach a greater catharsis.

When we compare the earlier epic to the subsequent tragedy, we can see that the Greeks had already moved from a mythological consciousness to more logical and philosophical thinking. Irrational myth was replaced by rational design and deliberate fiction - that is, mere belief retreated in favor of the public pretension of belief, or make-believe. The archetypal unifying myth, which presumably reflects a break towards the patriarchate in fear of the earlier amazon-like matriarchate, was no longer a sacred and untouched 
story, but rather the subject of continuous retellings. Double-tongued fiction was emerging as a new norm.

That the myth of Oedipus became known as a tragedy was only one possibility; the alternative, that it be instead considered a comedy, was likewise a completely realistic line of development. This is referenced by Sophocles' contemporary comedic kylix painting, currently displayed in the Vatican Museum, which depicts Oedipus flirting with a feminine sphinx and is covered with many joyous phallic symbols that one could hardly call morbid.

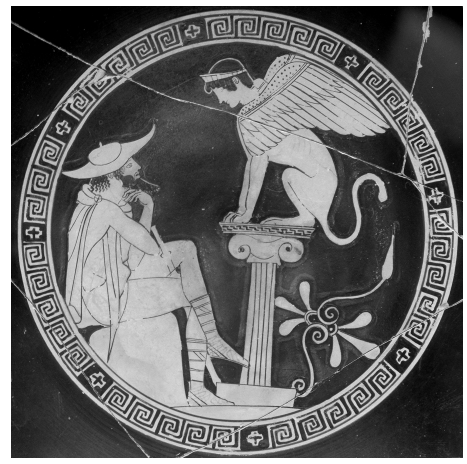

Attic cup: Oedipus and the Sphin $x^{2}$

\section{Thomas Hardy's Tess of the d'Urbervilles}

This great work (1891) emphasizing the age of "Victorian hypocrisy" uses, upon closer inspection, a similar model to that of the Greek tragedy. Researchers have highlighted Hardy's (who was quite familiar with Aeschylus) observation in his late notes and consider it to be his definition of tragedy: "The best tragedy - the highest tragedy in short - is that of the worthy encompassed by the inevitable. The tragedies of immoral and worthless people are not of the best" (Hardy, F. E. 1930: 14, Chen Zhen: 47). However, it is obvious that this is not Hardy's original idea but an extract from Aristotle's Poetics. It can be assumed that Hardy - unlike Nietzsche - did not ignore the shock-motif criticized there, which, according to Aristotle, accompanies the most noble portrayal of happiness turned to misfortune, whereas second-tier noble and moral characters, such as Oedipus, are better suited to being tragic heroes.

2 Interior of an Attic red-figured kylix, c. 470 bce; in the Gregorian Etruscan Museum, the Vatican Museums. Photo: Carole Raddato / Wikimedia Commons. 
MERILAI

The same can be assumed also about Hardy's own relationship with his protagonist. In this "Oedipal" model, Tess - as the successor of a fallen family of foreign invaders - despite all her tragic ironic goodness had to be secondary in the hierarchy of stature in the face of local gods. This perception is convincingly supported by the narrator's distancing and, at times, comical or even sarcastic descriptions of depressing events. His choice of words is all too indicative throughout the entire novel. If it was not made explicit earlier, then the parallel scene of antiquity is revealed as an influential symbolic picture in the climax of the work, where dark, long theatrical figures, hands, and faces arrive to arrest Tess, who is sleeping on the "sun victim" stone between Stonehenge's pagan pillars as the first rays of silver light begin to appear - the black togas and white masks are contrasted with the green-gray background of the stones.

Not even Angel Clare, with all his Christian love, can help; more primordial forces take over the situation. Characteristically, the narrator gives - with his unmistakable distant input with his sacrificial animal, without being detrimental to the reader's compassion - a clearly ambiguous commentary about the ending section of the book: "Justice" was done, and the President of the Immortals, in Aeschylean phrase, had ended his sport with Tess. And the d'Urberville knights and dames slept on in their tombs unknowing" (Hardy 2013: LIX). It is obvious that the work reflects unfair justice or, in other words, creates a revenge motif, which could also be reconstructed in the shadowed authorial application of King Oedipus. However, the possibility for comedy is also not lacking at the threshold, insofar as the Wagner-like scene of grandiose tragedy seems to be somewhat even moderately paradoxically inclined - "under the uniform concavity of black cloud" which "was lifting bodily like the lid of a pot" (Hardy 2013: LVIII; Radford 2002: 3-4). Unfortunately, this type of reversal in interpretation of the fixed canon is not widespread today, even though it would not harm these great works in any way and would only add to the dialogic richness of interpretation.

To add examples to this claim, we should construct a selective list of ironic wordings or motifs in which the author's dual attitude appears as an obvious counterpoint. The phrase about the immortal president originates from the tragedy of Aeschylus, Prometheus Bound. Let us also assume that poor Tess' liver is systematically pecked at throughout the book before finally finding peace in death. What a contrast of tragic irony: the most noble and pure will end up a raped, childless murderer. Yet an even stranger reference remains in the work's emotionally raised coda: a young sister and a depressed widow hold hands after Tess' execution and step forward into the future (similar to how Mäeküla Mari steps into the city with her step-child). This should mean that the entertaining sport, i.e. "druidic" curse that lay on the d'Urbervilles simply continues. This skeptical punchline - or the return of the alien-monster crossbreed - although 
already a cliché in contemporary horror films - has remained unnoticed in the enclosed schemes of the predominant glorifying interpretations. ${ }^{3}$

The shadowy, dark line of revenge associated with the then-conqueror's lineage, undefined by nature and with hints of pagan sun worship, may even be interpreted as an irrational vendetta, since the blood and its representative red color has been frequently highlighted on the path of Tess' suffering. Just as the descendants of Sir Pagan d'Urberville, the Norman companion of William the Conqueror, are announced, the diversely sanguineous, ominous Macbethian motifs begin to reveal themselves: the unlucky girl-child of nature is both physically and spiritually eroded until her lethal end. The tone is set by Tess' nighttime drive to the market in place of her father: during a traffic accident, the entrails of their only excuse for a horse, Prince, are torn apart, spraying crimson drops of blood all over Tess's face and dress. Even here, the writer displays comical distance, describing in smirking tones how Prince's carcass in her father's words, their chivalrous "charger" - was hoisted, at last, onto the carriage that he had only yesterday pulled himself, "with his hoofs in the air, and his shoes shining in the setting sunlight", so they can grieve and bury him in a hole at their home (Hardy 2013: IV). A dark and deadly night, a crisscrossed trail of blood, and the morning sunshine are a common scenography of Hardy's turning points. This seems to instill an image of Tess' destiny as a blood-stained princess.

Now feeling as if she were a murderer, Tess' guilt triggers a chain of subsequent events - she can no longer escape (as a Kristeva-like "Oedipal" scapegoat, abjection) from the bloody shadow of her distant ancestors. The victim's blood drips onto Tess from the wounded pheasants in the treetops, and from the heart of the murdered bringer of ruin, through a white ceiling, down into the room; a tavern, the color of fresh blood, the glowing cigar tip of the repentant rapist Alec, the chopping threshing machine, the letter on its way to the home of the husband's parents, a fanatic's apocalyptical graffiti on the county's walls and gardens, as well as the gallows house made from russet bricks, etc. - there are constant ominous allusions to blood and vengeance (see also Fisher 1992: 157). In any case, it is important to note that the writer does not passively depict Tess'

3 Insofar as Hardy's Tess is a perfect fit for criticism of segregation and patriarchal asymmetry, the surface receptions are the global fashion (see Fisher 1992, Kun Yu 2011, Spenser 1993, Rode 2005, Heffernan 2010, Badja 2011-2012, Hooti 2011). The socio-critical view makes undoubtedly sense, but we could still step over trivialities. That is how Hardy's tragic gaze is differentiated from his sarcastic dark humor by Andrew Radford in the monograph Thomas Hardy and the Survivals of Time (2003). 
MERILAI

predetermined sad reality; he himself creates the tragic curve: he has securely designed this trajectory, or in other words, everything that happens to Tess has been planned and deliberately constructed.

This goes for any kind of Demiurge type "cruelty", even when considering the flower pot at the baby Sorrow's grave in the corner of the cemetery for shady loved ones, on which hangs the sign "Keelwell's Marmelade." The infant's sad infirmity could be a clear counterexample in response to the spreading viewpoint that Tess is a sincere and naive child of nature who falls short of the restrictive norms set by patriarchal society. But nature, unfortunately, aborts this idea, since the monopoly seems to belong rather to a native radiant motherland than to the land's later "urban" conquerors. The demonic shade that accompanies Tess becomes more and more corrosive. For example, as shown in the way the brothers and sisters view the reversed (i.e., diabolical) candleflame sparking in the eyes of their elder sister, who is ecstatic from faith and secretly baptizing the dying baby. The writer has recognized Tess as inappropriate: she, who combines folkloric beauty with the ancient hinterland from her mother's side, but a violent curse from her father's side, has been split into a frail association. Thus, the Darbyfields are finally removed from the nest, just as their paternal ancestors once left the local people homeless and country-less. The pagan spirit did not contain Gospel teachings; only life and death, night and day prevailed, without shadows or compassion. Paradoxically, a biblical fire-verse also supports this on the gate: "THY, DAMNATION, SLUMBERETH, NOT.” / 2 Pet. II. 3. (Hardy 2013: XII). A creature like Tess has no access to any god and mercy.

Thus, the boundary of meaning with Tess as a pure and innocent sufferer, and Tess as a blood-guilty, degenerate "countess" are in fatal conflict: by favoring one, the writer, however, does not deny the other, but accepts the incompatible counterpoint, both the positive and negative field of meaning. ${ }^{4}$ This is a tragedy with unresolved conflict: the downfall of a worthy person due to higher inevitable forces in a dimension that exceeds personal will. Tess' particular decline, which can be considered her moral death before her final physical death, is achieved when she eventually consents to sleeping with the perpetrator of her ruin - even enduring efforts at piety for both herself and her family. The slaughter is simply the logical consequence of this mistake: society had been right from the beginning, the purest of the pure became the plaything

\footnotetext{
Although Angel Clare considers Tess' name to be shortened from Theresa, the title of the historical, pre-Tess narrative "The First Countess of Wessex" offers some idea about the meaning of her name. It is not without importance that the writer's mother, Jemima Hand, is considered the prototype of the title character of this story.
} 
of a dark destiny and, in the face of unwritten and written laws, ended up a murderer who became a prostitute for material gain. Tess' gradual erosion into a corpse, finally "drifting into acquiescence" (Hardy 2013: XXVIII), manifests itself as a mythical beginning with excessive depth, or in other words, a wicked irrational desire - the unexplained grudge of ancient shadows - perhaps even more than the social or patriarchal temporal paradigm of inevitability by which the novel has been mainly - and, unfortunately, relatively poorly and onesidedly - interpreted.

Therefore, this is not just a social novel, but a mythical proclamation. The idea behind the survival and contemporary hidden influence of ancient relics - fossils, remnants, myths, rituals - is the ideological foundation of Hardy's entire creation: just as sweet singing of a prehistoric archaeopteryx remains in the oscillation of the today's soundwaves - as it was expressed in his poem "In a Museum" (Hardy 1917: 7) -, dark pagan rituals are also heard throughout our reality, (Radford 2002: 28-29). Hegel's spiritual phenomenological background seems to be set philosophically in this vision.

Leave the intriguing references to the novel's autobiographical undertones, however, to the Hardy experts. Though it is known that the writer originally even considered the title "Tess of the Hardys," he quickly abandoned it due to its excessive personal reference (Millgate 1982: 294). Whatever stands out in the background of the preceding discussion, the writer's hidden ambivalence toward his parents, and especially his mother Jemima, is precisely one of several facts in the family narrative on which many of the fundamental motifs of the novel have been based. Open conflicts about a mother carrying out her ambitions through her son are not rare in his work. Also, Hardy's own conception, a Sorrow-style infancy fluctuating between life and death, is a personal motif (Millgate 1982: 3-23). Therefore, if a partial prototype of Hardy's mother lives in Tess, alongside others, then both strong love and opposing urges of aggression are simultaneously directed at her, probably leaving the problem unsolved. Hardy does not seem to be hypocritical in the negative sense of the word, but he artistically enriches ambivalence as the creator of a double-tongued - or classical tragic irony of fate-system of imagery.

Hardy's sentimental poem “Tess's Lament” (Hardy 1901: 232-234) has been, however, in some ways a counterexample, solved only from the viewpoint of a woman's personal love tragedy, without referring to the least excessive or supernatural cognition, as found in the subtext of the novel or in the main message of the poem "In a Museum." Although it is true that the heroine in the novel never comprehends the classical tragic irony of her fate (unlike Oedipus, who, as an archetypal detective, researched the truth himself), it is left to the author and his readers to make these extradiegetic observations. 
MERILAI

The keening is truly one-sided, without counterpoint or a competing line of meaning, which also apparently contributes to the impoverishment of the novel's reception. This is not the dirge of the d'Urberville family - a historicalpolitical and conjointly principally mystical lament of a decadent woman -, but rather something more personal for Tess - who, ultimately, desires and deserves happiness.

\section{Eduard Vilde's Mäeküla piimamees ('The Milkman of the Manor')}

Moving on from Wessex County's fictional milkmaid, Tess, we can now investigate Estonia's own Mäeküla milkmaid. Perhaps Eduard Vilde was acquainted with both Sophocles' tragedy as well as with Nietzsche and Freud; as a Germanspeaker, whether he read Hardy is unknown, but Tess von d'Urbervilles was published already in 1895. Having been raised in a peasant environment, Vilde was fully capable of writing about rural life without relying on outside influence; however, the issue of women's emancipation, oppressed by the social framework of the time, was also a constant concern for the Estonian writer.

I published a comprehensive article about Mäeküla piimamees as "the first Estonian erotic novel" (see Merilai 2011/2009), which - similarly to the analysis of preceding works -highlights through close-reading the two-fold attitude of the first Estonian novelist towards his heroine. In its reception, Vilde's social-democratic ideology, which strongly valued early feminism, was still highly regarded in both normal and Soviet times. At the same time, observation of the text brings out the author's latent erotomanic glance, which - typically "masculine" - treats the woman as a marketable sexual object. In his lust, he raises himself up in a privileged manner, while also humiliating the other sex with a rather "slave-like" attitude. Vilde was undoubtedly more socially advanced within the patriarchal context of his time, but the birthmarks of the previous era do not easily fade.

Vilde's ambivalent attitude towards his wayward heroine makes her an interesting character whose mystery cannot be solved unequivocally. Perhaps the unsolved question remains at the level of her awareness, which is open to speculation: Was the author naturally and spontaneously ambivalent toward his protagonist, splitting himself between the socially theoretical and privately sexual spheres? Did he not understand or does he simply not wish to bring these fields together? Was he blind to or aware of his double-tonguedness and thus more classically hypocritical and accepting of the contradictory social distance that comes with socialism? 
About the plot: the novel depicts a love triangle and the signing of a pact with the Devil. In it, Vilde analyzes the Estonian-German relationship, the subject matter of his former historical trilogy, while transferring tensions to the present, a time when the landed gentry no longer had the right to use physical force to discipline their subalterns. The freaky landlord von Kremer, an old bachelor, falls in love with a young peasant woman, Mari, who has just married her deceased sister's husband to take care of her two children. Fifty years earlier, it would have been easy to bed her. In the present, the ancient ius primae noctis, the legendary right of the first night, no longer exists, if it ever existed at all. Kremer solves his problem by bartering a decent deal. He offers Mari's husband, Prillup, a job as milkman of the manor in exchange for sexual favors with his wife. At first, Mari strictly refuses to take part in this kind of dubious business. Vilde's irony reaches its peak when he describes how Prillup tries to change his wife's mind. At last, she, an innocent child of nature, but strong and independent enough to decide on her own, consents of her own free will, perhaps out of mere curiosity, and her husband gets the position. This job becomes Prillup's undoing, as he slowly individuates and falls apart inwardly, mocked by the village people, and dies. Mari rejects Kremer's dalliance sessions in the manor and leaves for the city together with her sister's daughter to get on with her life, determined to be rid of all the perversity. We do not know their future destiny, but it sounds optimistic as the new proletarian era.

It can be noted that the author follows the events and people of the book in part through the eyes of the manor, in which a clear intention and masculine identification is apparent. The neologism "unknowingly", presented at the start of the novel (Vilde 1974: 17; in translation Vilde 1976: 30), hints that the spiritually awoken Vilde has become more or less aware of the newer Freudian theory of unconsciousness - that the following should also be read in a "psychologically" modern way. Vilde himself commented that the novel's "fundamental problem is social; with this I am fulfilling the psychological tasks set for myself” (Alttoa 1973: 326). It can be argued and also proven with keywords that Vilde encoded all primary sexual deviations in his novel, meaning it is full of sexual symbolism, which takes an average psychiatric handbook to enumerate: from onanism, fetishism, voyeurism, and homosexuality to geronto-, zoo-, pedo-, necro-, or coprophilia to sado-masochistic psychedelia. But the "psychological" point of view, just as with Freudian psychoanalysis, is inevitably also centered on a describer or analyst whose descriptive equalization is primarily a self-projection. Thus, by acquiring the gaze of the nobility and then applying the necessary writer's fantasy, a certain "eats and denies" contradiction arises: a socialist who fights passionately for equality and emancipation, but who is also a bourgeois aristocrat, granting 
himself the opportunity to enjoy life's pleasures. Opportunistic erotomanic voyeurism, on the one hand, the public condemnation of the act as an abolition of human dignity, on the other. Coexistence of controversial desire refers to hysteria in psychiatric terms. Vilde does not seem to be able to escape this, and it is questionable whether he would like to at all: because, if possible, why not have one's cake and eat it too.

One may also speculate from an oedipal standpoint - this time without the use of quotation marks - that traits of his active mother are hidden in each of Vilde's positive female characters - "sun women" as they are called in fiction - since the relationship between mother and son was supportive and understanding. As Vilde gravitated towards the motifs of the right of the first night and the estate owner's bastard child, it can be assumed that some traits from his father, who was promoted in the estate's hierarchy, have been implicitly transferred to Prillup's fraught character. Be that as it may, but the fictional Mari, as a strong and confident milkmaid, seems to be more culturally sublimated, more acceptably idealized for the reader, even though her private games with the manor's owner are not at all something anyone could be proud of in the name of women's emancipation. How can we prove that this is not "pedophilia" or masked "pornography" involving a child of nature, but rather a noble erotic novel with a socio-critical purpose? One possible answer is to consider that the woman in this novel is not a passive object (as she is sometimes interpreted), but an increasingly active and energetic subject, who decides for herself what she will do and how she will do it - and laughs at powerless men.

Contemporary criticism, more than demanding on the best of days, was suddenly stunned - a masterpiece had been born. Friedebert Tuglas, a critic with some authority belonging to the revolutionary group "Noor-Eesti" (Young Estonia), who used to consider Vilde a touristic hedonist, changed his mind radically only when this novel was published. The artistic quality struck him in the same way it did the "aristocrat of the spirit" Karl August Hindrey, who considered this "fine work" to be "our first real novel" (Tuglas 1959; Alttoa 1973: 341). Of course, Vilde was attacked from time to time, as is known, for his erotic inclinations, as did socialism's patriarch, Mihkel Martna, in criticizing Prophet Maltsvet, the third novel of Vilde's historical trilogy (Alttoa 1973: $254,326)$. But this obscenity of a lactation game is forgiven and forgotten throughout the course of the suggestive narrative, so much so that it was to be taught to children in schools as a future goal of social liberation.

In conclusion, Mäeküla piimamees is not without the same type of authorial ambivalence found in Oedipus the King or Tess of the d'Urbervilles, as Vilde also depicts his main character with dual intensions: feeling sympathy toward the victim, or so-called poetic tears, but - as a creator of pleasure - taking that 
same character to the sacrificial altar and methodically destroying his/her to heighten emotional reception. However, a clearly distinguishable two-level structure of tragic irony - in which the character does not see what the author and reader know and subsequently fear - is either very weak or entirely absent in Vilde's work. The intuitive desire to warn Prillup and Mari and spare them from their questionable choice belongs to our "reader phenomenology." A more fundamental version of tragic irony - clear situational irony - is undoubtedly strongly in place: a farm girl, albeit in a suspicious manner, takes the control away from the patriarchs. Therefore, if one considers Mäeküla piimamees to be critical realism but not, at the same time, an erotic novel, then one will come up surprisingly empty in face of the mystery of Mari's strange behavior: Why did she still do it, even though she wasn't forced to? It wasn't inevitable. Clearly the author wanted to visualize and remember her: as both a product of naturalistic, restrictive circumstances, and as an arousing, purring, and scratching pussycat, who decides to play the game until she gets tires of it. Vilde created a woman he would covet most. It does not seem to be coincidental that the novel's final pages, its social final chord, were left unwritten for quite some time (he completed the manuscript only when his socialist wife, Linda Jürman, started to come up with it herself), since the main tension had already been resolved in the previous pages.

So, though well-known in Estonian literary history, the novel remains still in part unknown, although the readers have always had their intuitions. In Tuglas-style, we must reconcile ourselves to reassess our initial interpretations of Mäeküla piimamees as the first Estonian psychological novel, and consider it, even more than that, an erotic novel, valuable as a multidimensional work of art: full of moving beauty and vitality, open to interpretation - indeed "realistic." Thus: Estonia is also not lacking in its honorable "hypocritical" literature, with a tradition that extends back to antiquity.

\section{Arne Merilai}

arne.merilai@ut.ee

Tartu Ülikool

Ülikooli 16-110

51014 Tartu

EESTI / ESTONIA 
MERILAI

\section{References}

Alttoa, V. 1973. Eduard Vilde Sõnameistrina: Monograafia. Tallinn: Eesti Raamat.

Aristotle 2013. The Poetics of Aristotle. A Translation by S. H. Butcher, http://www. gutenberg.org/files/1974/1974-h/1974-h.htm (07.03.2018).

Badja, F. 2011-2012. The Position of Women in Thomas Hardy's Poetry. Dissertation Submitted for the Fulfillment of the Magister Degree. Mouloud MAMMERI University of Tizi-Ouzou, http://www.ummto.dz/IMG/pdf/these_en_pdf-2.pdf (01.02.2018).

Chen Zhen. Tess in Thomas Hardy's Tess of the D'Urbervilles: Victim of Social Prejudice and Male Dominance in Victorian Patriarchal Society, http://www.ritsumei.ac.jp/ $\mathrm{acd} / \mathrm{cg} / \mathrm{lt} / \mathrm{rb} / 600 / 600 \mathrm{PDF} / \mathrm{chen}$.PDF (07.03.2018).

Deleuze, G.; Guattari, F. 2004. Anti-Oedipus: Capitalism and Schizophrenia. Translated by Robert Hurley, Mark Seem, Helen R. Lane. Preface by Michel Foucault. London, New York: Continuum.

Ehrenberg, V. 1954. Sophocles and Pericles. Oxford: Basil Blackwell.

Fisher, J. 1992. The Hidden Hardy. Houndmills etc.: Macmillan.

Hardy, F. E. 1930. The Later Years of Thomas Hardy 1892-1928. New York: Macmillan.

Hardy, T. 1901. Poems of the Past and the Present. New York-London, Harper and Brothers, https://archive.org/details/poemspastandpre00unkngoog (01.02.2018).

Hardy, T. 1917. Moments of Vision and Miscellaneous Verses. London: Macmillan, https://archive.org/details/cu31924013478122 (01.02.2018).

Hardy, T. 2013. Tess of the d'Urbervilles: A Pure Woman Faithfully Presented. The Project Gutenberg eBook. Prepared by Joseph E. Loewenstein, http://www.gutenberg. org/files/110/110-h/110-h.htm\#2 (07.03.2018).

Heffernan, J. A. W. 2010. "Cruel Persuasion": Seduction, Temptation, and Agency in Hardy's Tess, http://www.victorianweb.org/authors/hardy/heffernan.html (07.03. 2018).

Hegel, G. W. F. 1976. Ästhetik. Band 1. 3. Auflage. Berlin, Weimar: Aufbau.

Homer 1903. Iliad, Books XIII-XXIV with Notes by D. B. Monro, M.A. Fourth Edition, Revised. Oxford: Clarendon Press, https://archive.org/details/ iliadbooks1324wi1324homeuoft (01.02.2018).

Homer 1919. The Odyssey with an English Translation by A. T. Murray, PH.D. in two volumes. Cambridge, MA.: Harvard University Press; London: William Heinemann, Ltd., http://www.perseus.tufts.edu/hopper/text?doc=Perseus:text:1999.01.0136 (07.03.2018).

Hooti, N. 2011. The Apprehensive and Suppressed Soul of the Fallen Woman in Thomas Hardy's Tess of the D'Urbervilles. - Theory and Practice in Language Studies. Academy Publisher, Finland. Vol. 1, No. 6, pp. 630-634, http://www. academypublication.com/issues/past/tpls/vol01/06/08.pdf (07.03.2018).

Kristeva, J. 1982. Powers of Horror: An Essay on Abjection. Translated by Leon S. Roudiez. New York: Columbia University Press, 1982 (European Perspectives: A Series of the Columbia University Press). http://users.clas.ufl.edu/burt/ touchyfeelingsmaliciousobjects/Kristevapowersofhorrorabjection.pdf (retrieved 07.03.2018). 
Kun Yu 2011. The Causes of Tess's Tragedy. - Asian Social Science. Published by Canadian Center of Science and Education. Vol. 7, No. 1,71-74. http://www.ccsenet. org/journal/index.php/ass/article/viewFile/8863/6519 (retrieved 07.03.2018).

Merilai, A. 2011. Eduard Vilde Mäeküla piimamehe erootika. - A. Merilai, Vokimeister: Kriitilisi konstruktsioone 1990-2011. (Studia litteraria Estonica, 11.) Tartu: University of Tartu Press, 237-261.

Merilai, A. 2016. Autori kahekeelsus: Oidipus, Tess ja Mäeküla piimanaine. L. Kurvet-Käosaar, M. Laak, eds., Adressaadi dünaamika ja kirjanduse pingeväljad. (Studia litteraria Estonica, 18.) Tartu: University of Tartu Press, 13-35. (Summary: The Double-Tongued Author: Oedipus, Tess and the Milkwoman of the Manor, p. 309.)

Mihkla, K. 1972. Eduard Vilde elu ja looming. Tallinn: Eesti Raamat.

Millgate, M. 1982. Thomas Hardy: A Biography. New York: Random House.

Nietzsche, F. 2017. The Birth of Tragedy Out of the Spirit of Music. Translated by Ian Johnston, Vancouver Island University; Nanaimo, British Columbia, http:// johnstoniatexts.x10host.com/nietzsche/tragedyhtml.html (07.03.2018).

Radford, A. 2003. Thomas Hardy and the Survivals of Time. (The Nineteenth Century Series.) Aldershot, UK; Burlington, USA: Ashgate.

Rode, S. 2005. Sexual Identity on the Road in Tess of the D'Urbervilles. - Nineteenthcentury Gender Studies. Issue 1, Winter, http://www.ncgsjournal.com/issue1/rode. htm (01.02.2018).

Sophocles 2008. Oedipus King of Thebes. Translated into English Rhyming Verse with Explanatory Notes by Gilbert Murray. The Project Gutenberg Ebook, http://www. gutenberg.org/files/27673/27673-h/27673-h.htm (07.03.2018).

Spenser, T. 1993. Thomas Hardy: The Tragic Novels. Kent, UK: Crescent Moon Publishing.

Tuglas, F. 1959. Eduard Vilde: Mäeküla piimamees (1916). - F. Tuglas. Valik kriitilisi töid. Tallinn: Eesti Riiklik Kirjastus, 489-499.

Vilde, E. 1974. Mäeküla piimamees: Romaan. Tallinn: Eesti Raamat.

Vilde, E. 1976. Milkman of the Manor. Translated by M. Rauk. Tallinn: Eesti Raamat. 